\title{
Post-Treatment of Kennel Wastewater With Different Aeration Strategies
}

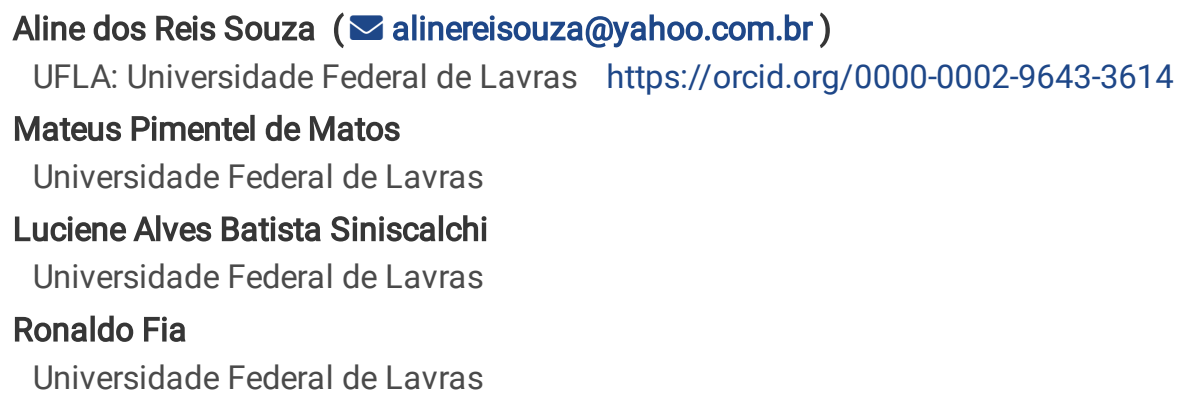

\section{Research Article}

Keywords: Cryptosporidium, dog waste, denitrification, aerated submerged biological filter, Giardia, nitrification, constructed wetlands

Posted Date: November 23rd, 2021

DOI: https://doi.org/10.21203/rs.3.rs-1008346/v1

License: (c) This work is licensed under a Creative Commons Attribution 4.0 International License. Read Full License 


\section{Abstract}

The objective of this study was to evaluate the effect of the introduction of a complementary aerobic treatment composed of a submerged aerated biological filter (SABF) with a secondary clarifier (SC), followed by horizontal subsurface flow constructed wetlands (CWs), after anaerobic units, on the ability to remove pollutants in different aeration phases (Ph1, Ph2, and Ph3) at the effluent treatment station of the Parque Francisco de Assis (PFA) dog shelter. Ph1 and Ph2 had 7 and 5 hours of daily aeration, respectively, and $\mathrm{Ph} 3$ had intermittent aeration every 2 hours. The phases were monitored regarding the removal efficiency of organic matter, solids, nutrients (N, P), coliforms, and detection of Giardia and Cryptosporidium. It was found that post-treatment provided greater removal efficiencies and that the aeration strategy of Ph3 showed mean efficiencies of $71 \%$ for COD removal and $77 \%$ for BOD removal, being similar or statistically higher, even with less biodegradable effluent, than those of Ph1 and Ph2. The SABF and SC removed $\mathrm{N}$ by nitrification and denitrification, leaving a total Kjeldahl nitrogen (TKN) concentration in the effluent of $18 \mathrm{mg} \mathrm{L}^{-1}$. The CW showed potential for simultaneous nitrification and denitrification (SND), in addition to solid filtration. The system did not satisfactorily remove thermotolerant coliforms (ThermC) $(1 \pm 0 \mathrm{log})$. PCR suggested the presence of the pathogens Giardia and Cryptosporidium in all post-treatment units in $\mathrm{Ph} 1$ and $\mathrm{Ph} 2$.

\section{Introduction}

The lack of or inefficient treatment of wastewater before it is returned to the environment may result in reduced levels of dissolved oxygen (DO) and eutrophication of the aquatic environment, in addition to contamination with microplastics, endocrine disruptors, heavy metals, and pathogenic organisms, causing environmental, economic, and aesthetic losses (Gao et al. 2012; Fowler et al. 2013; Eerkes-Medrano et al. 2015; Nascimento et al. 2015; Nazari-Sharabian et al. 2018; Vilela et al. 2018). In this context, it is essential to increase the percentage of wastewater treated and the efficiency levels of the different treatments.

The literature reports on effluents from swine, cattle, and aquaculture, among other sources (Matos and Matos 2017), however, there are still few studies on wastewater generated in dog shelters. The few existing references show a high solids concentration, the presence of pathogenic organisms, a high chemical oxygen demand/biological oxygen demand (COD/BOD) ratio, and higher nutrient concentration than that found in domestic sewage. Consequently, the effluent produced in kennels requires adequate biological treatment prior to discharge into the aquatic environment (Jaworski and Hickley 1962; Souza et al. 2018; Martins et al. 2019; Friedrich et al. 2020; Souza et al. 2020), being necessary to know the most efficient treatment alternatives for the purification of this wastewater.

In Brazil, a large number of wastewater treatment plants (WWTPs) still apply only primary and secondary anaerobic treatment stages, which is insufficient for reducing the concentration of nutrients, such as nitrogen $(\mathrm{N})$ and other compounds, before discharge into a waterbody. Systems that combine anaerobic and aerobic treatment with potential for nutrient removal are an alternative for improving wastewater treatment (Chernicharo et al. 2015; Brasil 2017).

Furthermore, to achieve biological $\mathrm{N}$ removal, it is necessary to alternate aerobic and anoxic conditions so that nitrification and denitrification and/or absorption of $\mathrm{N}$ inorganic forms occur (Zoppas et al. 2016; Wang et al. 2016; Martins et al. 2019; Friedrich et al. 2020; Souza et al. 2020). Denitrification is hindered in conventional WWTPs because to reduce nitrate $\left(\mathrm{NO}_{3}{ }^{-}\right)$to nitrogen gas $\left(\mathrm{N}_{2}\right)$, heterotrophic organisms need an organic carbon source, but a large part of the organic compounds are removed in previous stages (Marin et al. 2016). Operational strategies for increasing the denitrification capacity include the following: I) recirculating the nitratecontaining effluent, II) bypassing part of the raw wastewater directly to the anoxic zone, and III) introducing external sources of organic matter (Kunz et al., 2012; Capodaglio et al. 2016; Torrijos et al., 2016); however, these procedures are more complex and not readily accessible to all wastewater treatment facilities.

In attached growth reactors, such as biofilters and submerged aerated biological filters (SABFs), depending on the biofilm formation capacity, aerobic and anoxic zones may coexist, favoring N removal (Rocher et al. 2015; Pelaz et al. 2018; Souza et al. 2020). However, for there to be a greater potential for the occurrence of simultaneous nitrification and denitrification (SND), a supply of balanced DO concentrations should be provided; this can be achieved with reduced aeration rates or intermittent air blowing (llyas and Masih 2017; Pelaz et al. 2018; Souza et al. 2020). In addition, operating with a lower introduction of air into the reactor reduces electricity costs, making reactor adoption more accessible. 
Another treatment technology that can be employed in $\mathrm{N}$ removal is constructed wetland (CWs), units characterized by the presence of plants that both absorb pollutants and create aerated microzones in a predominantly anoxic and anaerobic environment, allowing nitrification and denitrification in the bed (Camacho et al. 2007; Tee et al. 2009, Coban et al. 2015; Souza et al. 2020). Moreover, denitrification seems to be more important in reducing the concentration of $\mathrm{NO}_{3}{ }^{-}$, while absorption by plants contributes significantly to the removal of $\mathrm{NH}_{4+}$ (Hallin et al. 2015; Wang et al. 2016; Gargallo et al., 2017). Given this potential, the lower costs and the simplicity of construction, operation, and maintenance, $\mathrm{CWs}$ have been recommended as decentralized solutions for effluent treatment (Avellán and Gremillion 2019).

Thus, the combination of SABFs and CWs, which has been shown to be effective in the removal of different pollutants in various wastewaters, could help reduce the load of $\mathrm{N}$ and other compounds discharged into the environment, such as organic matter and solids (Lizama et al. 2011; He et al. 2013; Li et al. 2013; Avelar et al. 2014; Priya and Philip 2015; Tao et al. 2016; Ramos et al. 2017; Souza et al. 2020), from kennel wastewater.

Souza et al. (2018) evaluated the characteristics of kennel wastewater and observed that a simplified treatment consisting of a septic tank-anaerobic filter (ST-ANF) unit and stabilization tanks (operating as anaerobic lagoons) was not sufficient to meet the standards for discharge into waterbodies, especially those regarding $\mathrm{N}$. Therefore, it is necessary to evaluate post-treatment alternatives that combine performance, savings, and operational simplicity for kennels.

Thus, the objective of the present study was to evaluate the introduction of aerobic post-treatment, composed of an SABF and CWs, and the effects of different aeration strategies in the SABF regarding the removal of pollutants by the WWTP of a kennel.

\section{Materials And Methods}

\subsection{Description of the wastewater and treatment system}

The wastewater evaluated in the present study is generated at the Parque Francisco de Assis (PFA) kennel in batches during the daily cleaning, between 9 am and $4 \mathrm{pm}$ (7 continuous hours) of the stalls of approximately 450 dogs after the solid waste is scraped. This effluent is sent to the PFA-WWTP at an average daily flow rate of $0.08 \mathrm{~L} \mathrm{~s}^{-1}$ and a hydraulic retention time (HRT) of 12 hours (Franco et al. 2018; Souza et al. 2018; Souza et al. 2020).

The WWTP is composed of two parallel systems of preliminary and primary/secondary anaerobic treatments that receive different amounts of wastewater because the WWTP was built on uneven terrain. One of these systems, which receive the largest volume of wastewater, performs preliminary treatment by grating and primary treatment in a 4- $\mathrm{m}^{3}$ clarifier. Next, the wastewater is directed to a primary/secondary treatment unit consisting of an ST-ANF unit with $10 \mathrm{~m}^{3}$ of capacity. The other treatment system, which receives the lowest volume of wastewater, is composed of grating followed by an ST-ANF with $5 \mathrm{~m}^{3}$ of capacity, without a clarifier (Figure 1) (Franco et al. 2018; Souza et al. 2018; Souza et al. 2020).

The effluents from the two anaerobic systems are mixed in a 2- $\mathrm{m}^{3}$ tank, from which they are pumped to the aerobic treatment system, consisting of a $25-\mathrm{m}^{3}$ SABF filled with $\mathrm{n}^{\circ} .4$ gravel (mesh opening between $50 \mathrm{~mm}$ and $76 \mathrm{~mm}$ ), followed by ten 2- $\mathrm{m}^{3}$ tanks, in series, of which six are secondary clarifiers (SCs), three are horizontal subsurface flow constructed wetlands (HSSF-CWs) filled with $n^{\circ} .0$ gravel (diameter between $4.8 \mathrm{~mm}$ and $9.5 \mathrm{~mm}$ ) and cultivated with vetiver grass (Chrysopogon zizanioides), and the last one is a passage and filtration tank filled with $\mathrm{n}^{\circ} .0$ gravel. The treated effluent is discharged into the Ribeirão do Camarão stream (Figure 1) (Franco et al. 2018; Souza et al. 2018; Souza et al. 2020). In the study by Souza et al. (2018), the ten tanks were used as stabilization pond units but were not efficient enough to allow effluent discharge into the cited watercourse, considering Minas Gerais State Resolution COPAM 01/2008 (Minas Gerais, 2008). Because PFA is an institution that relies on donations, any adopted wastewater treatment system should consider economical alternatives, such as the use of water tanks.

Regarding the maintenance of the WWTP, the grates and clarifier (primary treatment) are cleaned daily, the ST-ANFs every six months, and the SCs every 3 or 4 months to remove all the bottom sludge accumulated in the tanks (Franco et al. 2018; Souza et al. 2020).

\subsection{Aeration phases and system monitoring}


The physical, chemical, and microbiological variables were monitored at all treatment stages by collecting effluent at the following points (Figure 1): P1A - grating of the larger ST-ANF unit, P1B - grating of the smaller ST-ANF unit, P2A - after the larger ST-ANF unit, P2B - after the smaller ST-ANF unit, P3 - effluent pumping tank of the A and B ST-ANF units (inflow into the SABF), P4 - outflow from the SABF, P5 - outflow from the last SC, and P6 - outflow from the last CW.

Monitoring was performed during periods with different SABF aeration times, with an oxygen application rate of $0.28 \mathrm{~g} \mathrm{~L}^{-1} \mathrm{~h}^{-1} \mathrm{O}_{2}$. These periods were classified as Phase 1 (Ph1), Phase 2 (Ph2), and Phase 3 (Ph3), according to Table 1 (Souza et al. 2020).

Table 1

Aeration time, monitoring period and oxygen application rate in the submerged aerated biological filter used in the treatment of kennel wastewater, in the analyzed phases

\begin{tabular}{|c|c|c|c|}
\hline Phases & Aeration time & Monitoring period & $\begin{array}{l}\text { Application rate } \\
\mathrm{g} \mathrm{L}^{-1} \mathrm{~d}^{-1} \text { de } \mathrm{O}_{2}\end{array}$ \\
\hline $\mathrm{Ph} 1$ & $\begin{array}{l}\text { Same as effluent generation period, from } 9 \text { am to } 4 \mathrm{pm} \\
\text { ( } 7 \text { hours daily uninterrupted) }\end{array}$ & 5 months & 1.96 \\
\hline $\mathrm{Ph} 2$ & Aeration less than $\mathrm{F} 1$, from 9 am to $2 \mathrm{pm}$ ( 5 uninterrupted daily hours) & 6 months & 1.40 \\
\hline Ph3 & $\begin{array}{l}\text { Intermittent aeration } \\
\text { (every two hours for } 24 \text { hours per day) }\end{array}$ & Approximately 3 months & 3.36 \\
\hline
\end{tabular}

\subsection{Physical, chemical, and microbiological analyses}

For the physical and chemical analyses, simple samplings of the wastewater were performed weekly at all monitoring points, using a previously cleaned polyethylene flask, for the duration of each phase.

The variables analyzed at the Wastewater Laboratory of the Department of Environmental Engineering of Federal University of Lavras (Universidade Federal de Lavras - UFLA) included the $\mathrm{pH}$ by the potentiometric method, total solids (TS) and suspended solids (SS) by gravimetry, biochemical oxygen demand (BOD) by the Winkler method (titration), total phosphorus (TP) by the vanadomolybdate complex method with colorimetry through spectrophotometry, chemical oxygen demand (COD) by colorimetry after sample digestion under closed reflux, total Kjeldahl nitrogen (TKN) by the micro-Kjeldahl method, nitrite $\left(\mathrm{NO}_{2}{ }^{-}\right)$by colorimetry through the sulfanilamide method, nitrate $\left(\mathrm{NO}_{3}^{-}\right)$by colorimetry through the salicylate method, and thermotolerant coliforms (ThermC) by the multiple fermentation method. All methods followed the recommendations of Apha et al. (2005) and Matos (2012). The Total Nitrogen (TN) values were calculated by summing the concentrations of TKN, nitrites and nitrates.

The removal efficiencies in each treatment unit and in the system as a whole were calculated from the weekly results.

The data were subjected to Tukey's and t test at a $5 \%$ significance level to assess whether the means were significantly different from each other. The test was performed using STATISTICA ${ }^{\circledR}$ software.

\subsection{DNA extraction and molecular analysis by PCR for the detection of Giardia and Cryptosporidium}

The last samples from the SABF, SC, and CWs (P4, P5, and P6) from aeration phases 1 and 2 (obtaining a microbiota more adapted to the condition of each phase) were tested for the protozoans Giardia and Cryptosporidium by polymerase chain reaction (PCR). The samples underwent basic sedimentation and sludge separation procedures. The sludge was pipetted ( $2 \mathrm{~mL}$ to $5 \mathrm{~mL}$ ), stored in Eppendorf tubes, and sent to the Laboratory of Water and Sewage Microbiology of the Department of Sanitary and Environmental Engineering of Federal University of Minas Gerais (Universidade Federal de Minas Gerais (UFMG)).

The samples with the sludge were centrifuged at 4,000 rpm for 20 minutes, washed three times with phosphate-saline buffer (PBS $1 \mathrm{X}$, $\mathrm{NaCl}, \mathrm{Na}_{2} \mathrm{HPO}_{4}, \mathrm{NaH}_{2} \mathrm{PO}_{4}, \mathrm{pH}=7.2-7.4$ ), weighed, and stored at $-20{ }^{\circ} \mathrm{C}$. 
Genomic DNA was extracted from 0.5-g aliquots of all samples using the FastDNA ${ }^{\circledR}$ SPIN Kit for Soil (MP Biomedicals) according to the manufacturer's instructions. Aliquots of $3.0 \mu \mathrm{L}$ of DNA extracted from the samples were subjected to electrophoresis in a $1.2 \%$ agarose gel ( 80 volts, 40 minutes) to determine the result, followed by quantification in a Nanodrop 1000 spectrophotometer (Thermo Scientific).

For PCR, primers P241F-P241R for Giardia and P702F-P702R for Cryptosporidium were used at a concentration of $30 \mathrm{pmol}^{-1} \mathrm{~L}^{-1}$. A premix (Phoneutria, Brazil) containing standard buffer, nucleotides, and Taq polymerase was used in the PCR. The annealing temperature followed the specifications of each primer. The presence and size of the amplified fragments were visualized on a $1 \%$ agarose gel with a $2-\mu \mathrm{L}$ aliquot of the PCR product. Negative controls containing only the PCR reagent and ultrapure water were used for quality control of the reactions.

\section{Results And Discussion}

The monitoring results are shown in Figure 2 and are discussed below by the treatment stage ( $A$ and $B$ anaerobic systems and aerobic post-treatment) and the system as a whole.

\subsection{A and B anaerobic systems}

The mean $\mathrm{pH}$ values of the effluent inflowing into the two anaerobic treatment systems (Figure 2a, b, and c) were higher than the typical value (7.0) of domestic sewage (von Sperling 2017a), than that found by Silva and Souza (2011) in the studied ST-ANF (7.3), and than the optimal pH range for the development of methanogenic archaea (6.6 - 7.4) (Chernicharo 2007). Therefore, the system may not be performing well in terms of microbiological degradation, requiring $\mathrm{pH}$ control interventions.

In B system, however, the $\mathrm{pH}$ remained within the range reported by von Sperling (2017a), 6.7 to 8.0, while in A system, the mean $\mathrm{pH}$ was above the upper limit. This may be due to the presence of some chemical substances at higher concentrations in the effluent generated by the washing of the stalls, which is directed to P1A. The system in question covers more animals, in addition to stalls sheltering dogs that are undergoing treatment and receiving medication or that underwent surgical procedures. In addition to this hypothesis, the mean COD concentrations (Figure 2d, e, and f) found in system A, in the three phases, were higher than those in $B$ system. In both systems, the mean COD concentration was higher than the mean observed by Souza et al. (2018) of $334 \mathrm{mg} \mathrm{L}^{-1}$ in the same PFA reactors. However, the mean inflowing concentrations in both systems are within the range commonly found in domestic sewage (450 - $800 \mathrm{mg} \mathrm{L}^{-1}$ ) (von Sperling 2017a).

The mean BOD/COD ratio of the effluent inflowing into the system, calculated from the data presented in Figure $2 d, e, f, g, h$, and i, demonstrated that the effluent had low biodegradability, namely, 0.3 in Ph1 and 0.4 in Ph2 and Ph3, and thus a high inert fraction. This characteristic can be attributed to the presence of dog hair, oils and fats, cleaning and hygiene products, and medications used in the treatment of the dogs (Souza et al. 2018; von Sperling 2017a; Affandi et al. 2014; Kornillowicz-Kowalska and Bohacz 2011; Merrettig-Bruns and Jelen 2009).

Giustina et al. (2010) found COD concentrations in raw domestic sewage close to the mean in the effluent inflowing into the PFAWWTP, but with a biodegradability of 0.6 . The low biodegradability found in the PFA effluent does not prevent but can hinder biological treatment and, consequently, result in unsatisfactory organic matter removal efficiency (von Sperling 2017a).

The mean organic matter (BOD and COD) removal efficiencies in A and B systems were not satisfactory, as the removal expected for these treatment units, 80 to $85 \%$ for BOD and 70 to $80 \%$ for COD, was not achieved (von Sperling 2017a) and the minimum efficiency required by law for effluent discharge into waterbodies, $85 \%$ for BOD and 75\% for COD (Minas Gerais 2008), was not met (Table 2). The concentrations at the end of the anaerobic treatment were also higher than the maximum concentrations allowed for discharge into the stream ( $60 \mathrm{mg} \mathrm{L}^{-1} \mathrm{BOD}$ and $180 \mathrm{mg} \mathrm{L}^{-1} \mathrm{COD}$ ), with values of 226 and $172 \mathrm{mg} \mathrm{L}^{-1}$ for BOD and 751 and $616 \mathrm{mg} \mathrm{L}^{-1}$ for COD in $A$ and $B$ systems, respectively, without a significant difference $(p>0.05)$ in the comparison of the inlets and outlets of the systems. These findings justify the need to introduce the subsequent aerobic phase as a post-treatment, as already observed by Souza et al. (2018). 
Table 2

Mean efficiencies and standard deviation of removal of COD, BOD, TS, SS, TP, TKN and ThermC in anaerobic treatment systems A and B (ST-ANF), from PFA-WWTP (mean of all phases)

\begin{tabular}{|c|c|c|c|c|c|c|c|}
\hline \multirow{2}{*}{$\begin{array}{l}\text { Anaerobic } \\
\text { treatment }\end{array}$} & \multicolumn{6}{|c|}{$-\mathrm{P} 1$ - P2 (\%) } & \multirow{2}{*}{$\begin{array}{l}\text { P1A e P1B - P3 (log) } \\
\text { ThermC }\end{array}$} \\
\hline & COD & BOD & TS & SS & TP & TKN & \\
\hline A System & $20 \pm 28$ & $30 \pm 31$ & $25 \pm 25^{\star}$ & $42 \pm 32^{*}$ & $12 \pm 19$ & $23 \pm 38$ & $1 \pm 3$ \\
\hline B System & $17 \pm 16$ & $25 \pm 32$ & $12 \pm 21$ & $14 \pm 29$ & $5 \pm 28$ & $20 \pm 33$ & \\
\hline
\end{tabular}

Efficiencies higher than those found for ST-ANF units were reported in studies on domestic sewage, such as 59 and $77 \%$ for BOD and 53 and 79\% for COD (Oliveira and von Sperling 2005; Silva and Souza 2011; Moura et al. 2011); this difference may be related to the low biodegradability under anaerobic conditions of the effluent of the PFA-WWTP (Souza 2015).

The removal efficiencies of A system were higher than those of B system, not only for organic matter but also for solids and nutrients. As shown in Figure 2, A system has a primary clarifier before the ST-ANF unit, which helps to increase the efficiencies through the retention of solids, including organic compounds and nutrients (nitrogen and phosphorus) bound to the solids.

It is known the nutrient removal of anaerobic treatment units is limited (Chernicharo 2007). However, the phosphorus incorporated into the sludge in the clarifier or ST-ANF unit can be removed by heterotrophic bacteria that accumulate polyphosphates within the cell, depending on conditions favorable to their growth and metabolism (Henrique et al. 2010). In addition, with the pH above 8.0 in $\mathrm{A}$ system, physicochemical removal by phosphorus precipitation may have occurred; with the precipitate retained in the clarifier, nitrogen loss by ammonia volatilization may have been favored (von Sperling 2017b). These processes were reported by Vivan et al. (2010) at a pH of 8.5 in stabilization ponds.

In anaerobic systems, Moura et al. (2011) found removal efficiencies for TP ranging from 9.8 to $86 \%$ and TKN ranging from 15 to $77 \%$, while Oliveira and von Sperling (2005) found mean values of 30\% for TP and 24\% for TKN. According to von Sperling (2017a), no more than 35\% TP removal is expected in domestic sewage treatment by ST-ANF due to what was discussed by Lamego Neto and Costa (2011) and Zhang et al. (2017). According to these authors, for complete TKN removal, there must be variation in the redox potential in the environment. Thus, most TKN and TP are usually conserved during anaerobic treatment, with an increase only in the mineralized fraction.

Therefore, the efficiencies found in the anaerobic treatment of the PFA-WWTP were low, and there were no significant differences $(p>0.05)$ between the nutrient concentrations of the inlet and outlet of either system.

Figure $2 p, q, r, s, t$, and $u$ shows a frequent increase in the concentration of nutrients from the anaerobic units (P2A and P2B) due to the accumulation of the mineralized nutrient fraction in the sludge of the ST-ANF system, which undergoes dragging due to hydraulic load shocks or flows into the system, as demonstrated by Souza et al. (2018). In this sense, the TKN concentrations at the outlet of the anaerobic systems did not meet the legal requirement, with 46 and $29 \mathrm{mg} \mathrm{L}^{-1}$ in A and B systems, respectively, although the law establishes a limit only for ammonia- $\mathrm{N}$, of $20 \mathrm{mg} \mathrm{L}^{-1}$.

The removal of SS (Figure 2m, n, and o) was satisfactory in A system (which has a primary clarifier), meeting the threshold concentration established by law $\left(150 \mathrm{mg} \mathrm{L}^{-1}\right)$, with a mean of $89 \mathrm{mg} \mathrm{L}^{-1}$ and a significant difference between the inlet and outlet $(p<0.03)$. The mean SS concentration at the outlet of B system $\left(171 \mathrm{mg} \mathrm{L}^{-1}\right)$ (without primary clarifier) did not differ significantly from that at the inlet and did not comply with the threshold established by law. This shows that the primary clarifier used in the treatment of the PFA effluent is extremely important for reducing the SS input into the subsequent treatment stages of the PFA-WWTP. Moura et al. (2011) found SS removal efficiencies in an ST-ANF system ranging from 71 to $88 \%$, while Oliveira and von Sperling (2005) found a mean of $66 \%$, considering a total of 166 WWTPs with different configurations. According to von Sperling (2017a), the common SS removal range is $80-90 \%$ for domestic sewage; therefore, the efficiency of the ST-ANF units of PFA could be higher if better managed by periodically removing part of the sludge from the treatment units.

Regarding coliform removal, Oliveira and von Sperling (2005) found a mean efficiency of 79\% (0.9 log units) in ST-ANF systems, while von Sperling (2017a) reported a common range of 1 to 2 log units removed. Therefore, the efficiency found in the present study was 
within what is considered satisfactory (Figure 2v, w, and $\mathrm{x}$ ), although there were no significant differences between the inlet and outlet. In addition, the geometric mean at the outlet of the anaerobic treatments at P3 was still high, $2 \times 10^{6} \mathrm{MPN} 100 \mathrm{~mL}^{-1}$.

\subsection{Aerobic post-treatment}

As it was necessary to increase the efficiency of the PFA-WWTP, the facultative lagoons were replaced by an SABF, a clarifier, and CWs, and the contribution of the reactors is discussed below. The mean pH values (Figure 2a, b, and c) at P3 to P6 remained within the range appropriate for the activity of nitrifying microorganisms, 6.0 to 8.0, and decreased throughout the treatment, indicating nitrification since $\mathrm{H}^{+}$ions are released in the involved reactions (von Sperling 2012; Zoppas et al. 2016).

Nitrification was higher at P4 (aerobic treatment by SABF) than in the other post-treatment units (Figure 3a and b), as expected, with higher nitrite and nitrate concentrations due to the air blowing and aerobic conditions, which are favorable to the activity of nitrifying bacteria (nitrosation and nitration).

Using the Tukey test, it was observed that only for the variable BOD there was a significant difference in the influent concentration in the different phases. The BOD concentration in phase 3 was significantly lower than in phase 2 . Then, indicating that differences in post-treatment performance can be explained to the aeration conditions.

The nitrosation (Figure 3a) and nitration (Figure 3b) in the SABF were significantly higher in $\mathrm{Ph} 3$ (intermittent aeration and higher $\mathrm{O}_{2}$ supply), with higher mean concentrations of nitrite $\left(0.05 \mathrm{mg} \mathrm{L}^{-1}\right)$ and nitrate $\left(3 \mathrm{mg} \mathrm{L}^{-1}\right)$ than $\mathrm{Ph} 1(\mathrm{p}<0.02$ for nitrite and nitrate) and $\mathrm{Ph} 2$ ( $\mathrm{p}<0.001$ for nitrite; $\mathrm{p}<0.02$ for nitrate). The results are consistent with the nitrifying bacteria count performed by Souza et al. (2020), an evaluation that showed that the highest density of nitrifying bacteria was found in this phase.

The increase in the concentration of $\mathrm{NO}_{2}{ }^{-}$and $\mathrm{NO}_{3}{ }^{-}$resulted in a higher concentration at the $\mathrm{SABF}$ outlet in Ph3, reducing the removal efficiency, which could explain the fact that there was no significant difference in the removal of nitrites and nitrates in Phase 3 , as reported in Table 3.

Table 3

Average removal efficiencies of COD, BOD, TS, SS, TP, TKN, TN; NO2-, NO3- and ThermC in the aerobic post-treatment (SABF, SC and $\mathrm{CW})$, of the PFA-WWTP, in the different phases of aeration

\begin{tabular}{|c|c|c|c|c|c|c|c|c|c|c|c|}
\hline \multirow[t]{2}{*}{ Phase } & Step & COD & BOD & TS & SS & TP & TKN & TN & $\mathrm{NO}_{2}^{-}$ & $\mathrm{NO}_{3}^{-}$ & \multirow[t]{2}{*}{$\begin{array}{l}\text { ThermC } \\
\text { (log) }\end{array}$} \\
\hline & & \multicolumn{9}{|c|}{$\longrightarrow(\%)$} & \\
\hline \multirow[t]{3}{*}{$\mathrm{Ph} 1$} & SABF & $24 \pm 31 B$ & $44 \pm 29 A$ & $5 \pm 6 A$ & $1 \pm 5 \mathrm{~A}$ & $14 \pm 20 \mathrm{~A}$ & $29 \pm 30 A$ & $27 \pm 29 A$ & $7 \pm 12 A$ & $8 \pm 19 A$ & \multirow[t]{2}{*}{$0 \pm 0 \mathrm{~A}$} \\
\hline & SC & $3 \pm 9 B$ & $33 \pm 25 \mathrm{~A}$ & $22 \pm 14 \mathrm{~A}$ & $47 \pm 28 \mathrm{~A}$ & $11 \pm 14 \mathrm{~A}$ & $21 \pm 28 \mathrm{~A}$ & $21 \pm 28 \mathrm{~A}$ & $78 \pm 31 \mathrm{~A}$ & $28 \pm 30 A$ & \\
\hline & $\mathrm{CW}$ & $19 \pm 25 \mathrm{~A}$ & $53 \pm 32 A B$ & $13 \pm 16 \mathrm{~A}$ & $24 \pm 27 A$ & $23 \pm 25 \mathrm{~A}$ & $23 \pm 35 \mathrm{~A}$ & $22 \pm 34 \mathrm{~A}$ & $17 \pm 28 \mathrm{~A}$ & $7 \pm 15 A$ & $0 \pm 1 \mathrm{~A}$ \\
\hline \multirow[t]{3}{*}{$\mathrm{Ph} 2$} & SABF & $40 \pm 24 A B$ & $38 \pm 32 A$ & $3 \pm 6 \mathrm{~A}$ & $6 \pm 17 A$ & $5 \pm 13 \mathrm{~A}$ & $31 \pm 30 \mathrm{~A}$ & $30 \pm 29 A$ & $2 \pm 9 \mathrm{~A}$ & $9 \pm 16 \mathrm{~A}$ & \multirow[t]{2}{*}{$0 \pm 1 \mathrm{~A}$} \\
\hline & SC & $24 \pm 25 \mathrm{~A}$ & $51 \pm 23 A$ & $24 \pm 8 A$ & $63 \pm 22 \mathrm{~A}$ & $18 \pm 17 \mathrm{~A}$ & $17 \pm 24 \mathrm{~A}$ & $17 \pm 24 \mathrm{~A}$ & $80 \pm 21 \mathrm{~A}$ & $19 \pm 21 \mathrm{~A}$ & \\
\hline & $\mathrm{CW}$ & $34 \pm 31 \mathrm{~A}$ & $66 \pm 22 A$ & $12 \pm 9 \mathrm{~A}$ & $39 \pm 35 A$ & $12 \pm 14 \mathrm{~A}$ & $21 \pm 19 A$ & $20 \pm 19 A$ & $14 \pm 22 \mathrm{~A}$ & $13 \pm 20 \mathrm{~A}$ & $1 \pm 0 \mathrm{~A}$ \\
\hline \multirow[t]{3}{*}{$\mathrm{Ph} 3$} & SABF & $51 \pm 13 A$ & $19 \pm 19 A$ & $2 \pm 16 \mathrm{~A}$ & $10 \pm 30 \mathrm{~A}$ & $9 \pm 13 \mathrm{~A}$ & $14 \pm 26 \mathrm{~A}$ & $14 \pm 26 \mathrm{~A}$ & $0 \pm 0 \mathrm{~A}$ & $6 \pm 11 \mathrm{~A}$ & \multirow[t]{2}{*}{$1 \pm 0 \mathrm{~A}$} \\
\hline & SC & $23 \pm 19 A B$ & $38 \pm 32 A$ & $25 \pm 16 \mathrm{~A}$ & $47 \pm 23 \mathrm{~A}$ & $21 \pm 26 \mathrm{~A}$ & $35 \pm 31 \mathrm{~A}$ & $33 \pm 30 \mathrm{~A}$ & $11 \pm 15 B$ & $29 \pm 38 A$ & \\
\hline & $\mathrm{CW}$ & $23 \pm 27 A$ & $33 \pm 26 B$ & $16 \pm 11 \mathrm{~A}$ & $23 \pm 28 \mathrm{~A}$ & $8 \pm 14 \mathrm{~A}$ & $7 \pm 12 A$ & $5 \pm 9 A$ & $27 \pm 24 \mathrm{~A}$ & $22 \pm 30 A$ & $0 \pm 0 \mathrm{~A}$ \\
\hline
\end{tabular}

In SC (P5) Ph3, nitrosation remained constant, and there was no nitration, possibly due to the reduction in DO in this reactor, since at lower concentrations, from 0.3 to $0.7 \mathrm{mg} \mathrm{L}^{-1}$, there is a prevalence of ammonia oxidation because the bacteria responsible for nitration are sensitive to low oxygenation of the environment (Zeng et al. 2013; Luesken et al. 2011; Ge et al. 2015; Zoppas et al. 2016; Giongo et al. 2018; llyas and Masih 2017; Pelaz et al. 2018). Thus, in this anoxic environment, greater denitrification (nitrate removal) occurred 
than in the other units and phases, in terms of concentration (greater $\mathrm{NO}_{3}{ }^{-}$concentration), as there was no significant difference in efficiency (Table 3).

It can therefore be inferred that there was SND in the SC according to recent studies (Yao and Peng 2017; He et al. 2016; Kinh et al. 2017; Zheng et al. 2018). Therefore, in this phase, the highest density of denitrifiers was found in the SC, even though this phase had the highest oxygen supply (Souza et al. 2020). The explanation may lie in the favoring of heterotrophic aerobic nitrification by the intermittent aeration, enabling the proliferation of both nitrifying and denitrifying bacteria (He et al. 2016; Kinh et al. 2017; Zheng et al. 2018; Souza et al. 2020).

In Ph3, there was also greater accumulation of sludge in the SC reactor (Figure 2), making the environment more anaerobic, which favored greater adaptation of heterotrophic bacteria, reducing nitrate to nitrogen gas $\left(\mathrm{N}_{2}\right)$. Under these conditions, denitrifying bacteria may become predominant due to a higher growth rate and cell yield $\left(7.2 \mathrm{~d}^{-1} ; 0.43 \mathrm{~g} \mathrm{~g}^{-1} \mathrm{COD}\right)$, given the higher affınity for the substrate present (Beltran 2008; Nocko 2008; Zoppas et al. 2016; Metcalf and Eddy 2003). Consequently, there was greater N removal efficiency in the SC, with concentrations of $20 \mathrm{mg} \mathrm{L}^{-1}$ for total nitrogen (TN) and $18 \mathrm{mg} \mathrm{L}^{-1}$ for TKN, within the limit for discharge into waterbodies ( $\leq 20 \mathrm{mg} \mathrm{L}^{-1}$ ammonia-N).

In phases Ph1 and Ph2, the sludge accumulation was lower because periodic cleaning of the SC was performed every 7 months, occurring once at the beginning of the monitoring, again during Ph2, and coinciding with the end of the study; thus, Ph3 did not include a cleaning intervention. Another factor that may have contributed to the sludge accumulation in the SC in Ph3 was the greater oxygen supply. Aerobic treatments are commonly characterized by large sludge generation (von Sperling 2017a; Jordão and Pessoa 2017), as observed in P4 (Figure 2m, n, and o); therefore, a increased $\mathrm{O}_{2}$ availability contributed to greater organic degradation and sludge generation.

In Ph3, the SS concentration in the SC was $119 \mathrm{mg} \mathrm{L}^{-1}$, higher values than in other phases, however, the efficiencies of TS (dissolved and suspended) and TP retention were only numerically greater than in phases 1 and 2 (Table 3 ). It is known that TP removal is related to TS retention, through the incorporation of the nutrient in the microbial biomass and, consequently, in the removed sludge as discussed by Henrique et al. (2010). Due the greater production of sludge and the alternating of anaerobic and aerobic phases (Henrique et al. 2010; von Sperling 2017b), the expectation that the phase 3 would be the most effective phase. One hypothesis is that it is related to the need to remove accumulated sludge more frequently. However, notably, the SC, in all phases, was able to reduce the SS concentration to values acceptable by law ( $\leq 150 \mathrm{mg} \mathrm{L}^{-1}$ ) (Minas Gerais 2008).

Giustina et al. (2010) highlighted the need for devices to retain the sludge from the SABF. Due to the high sludge generation and low retention capacity of the analyzed biofilters (with $\mathrm{n}^{\circ} .4$ gravel, PET (Polyethylene terephthalate), and a Pall ring), a solid retention chamber after aerobic treatment was essential. According to these authors, due to the presence of the sludge retention chamber, immediately after the biofilter, it was possible to achieve a mean SS removal efficiency of $94 \%$ and a COD of $72 \%$. In addition to increasing the solids removal, the clarifier is important for increasing the service life of the CWs (Matos et al. 2018).

Higher organic matter degradation efficiency was observed, considering the COD removal in the SABF during Ph3 (statistically compared to phase 1), a period with greater applied aeration rate (Table 3), favoring the metabolism of heterotrophic organisms (von Sperling 2017b). Hasan et al. (2014) also detected a higher COD removal efficiency of $99 \%$ in the phase in which the aeration rate increased from 0 to $2 \mathrm{~L} \mathrm{~min}^{-1}$.

Souza et al. (2018) analyzed the PFA wastewater and identified greater COD removal capacity in the presence of oxygen, explained by the high difficult-to-biodegrade fraction, as previously described. At P3, the BOD/COD ratio was 0.4 in Ph1, 0.3 in Ph2, and 0.2 in Ph3, i.e., the effluent inflowing into the post-treatment showed even lower biodegradability since most of the biodegradable fraction was removed in the previous treatment by the ST-ANF unit (in the raw effluent, the average BOD/COD ratio is $0.4 ; 0.3 ; 0.3$, respectively). Thus, there was a greater percent reduction in the BOD concentrations than the COD concentrations by biological processes. It is noteworthy that, although the SABF affluent was less biodegradable in Phase 3 compared to Phase 2, with BOD concentration significantly lower, without the same occurring with COD, there was no significant difference in organic matter removal efficiencies. This condition indicates the importance of oxygen supply to increase the ability to remove organic matter.

The organic matter (BOD) removal by the SABF was complemented by the SC, which showed good efficiency; therefore, the BOD concentration at the outlet of the SC was $59 \mathrm{mg} \mathrm{L}^{-1}$ in Ph2 and $53 \mathrm{mg} \mathrm{L}^{-1}$ in Ph3, complying with the legal limit (60 mg L $^{-1}$ ), which was 
not the case for COD, except in Ph3. In the phase with the longest aeration time, the CW was able to reduce the COD concentration to acceptable values for discharge into the watercourse (180 $\mathrm{mg} \mathrm{L}^{-1}$ ) (Minas Gerais 2008), with an outlet concentration of $166 \mathrm{mg} \mathrm{L}^{-1}$.

As described in other studies (Lizama et al. 2011; He et al. 2013; Li et al. 2013; Avelar et al. 2014; Priya and Philip 2015; Tao et al. 2016; Ramos et al. 2017), the removal of P and especially of N was observed in the CWs in Ph1 and Ph2. However, due to the higher inflowing organic matter concentrations, which resulted in higher sludge generation in these phases, the treatment did not achieve the necessary efficiency. In contrast, in Ph3, there was an increase in nutrient concentration, given the accumulation of sludge in the SC and dragging to the CWs, reducing the removal capacity in the reactor. The mean concentrations were $25 \mathrm{mg} \mathrm{L}^{-1}$ for TN and $24 \mathrm{mg} \mathrm{L}^{-1}$ for TKN, values slightly higher than the limit of $20 \mathrm{mg} \mathrm{L}^{-1}$ for ammonia-N established by law. During this period, nitration (nitrite removal) and denitrification (nitrate removal) occurred in the reactors.

According to the literature, plants in CWs favor $\mathrm{N}$ removal by absorption and by oxygen absorption and pumping in the root zone, contributing to nitrification in aerobic microzones and to denitrification in predominantly anoxic or anaerobic regions (Adradros et al. 2014; Taylor et al. 2011; Sarmento et al. 2012; Samsó and García 2013; Avelar et al. 2014; Toscano et al. 2015; Fan et al. 2016). Therefore, there were conditions for SND to occur in the CWs, as observed by the nitration and denitrification efficiency data (Table 3 ). The co-occurrence of aerobic, anoxic, and anaerobic conditions within a CW can increase the nitrification and denitrification activity (Pelissari et al. 2017; 2018), with satisfactory results for TN removal, ranging from 40 to 70\% (Dong and Sun 2007; Huang et al. 2017; Pelissari et al. 2017; Saeed and Sun 2017).

The CW in Ph2 removed 1 log ThermC, as the SABF followed by the SC in Ph3, that showed better conditions for ThermC removal, which may be due to oxidation or competition with other microorganisms. However, the sludge dragged to the $\mathrm{CW}$ and, consequently, the accumulation of microorganisms may have reduced the inactivation conditions (as it could have happened on the $\mathrm{CW}$ in phase 3 ), considering that cultivated CWs operated with lower organic loads usually have a greater capacity for coliform removal due to the release of antimicrobial substances by plants (Avelar et al. 2014; Brix et al. 1989).

Regarding the detection performed by the PCR technique, the presence of the protozoan genera Giardia and Cryptosporidium was confirmed in the effluent samples in Ph1 and Ph2 at all analyzed stages (Table 4), confirming that the post-treatment was not able to remove pathogenic microorganisms.

Table 4

Results PCR's with specific primers for Giardia and Cryptosporidium at different sampling points of the kennel WWTP

\begin{tabular}{|lll|}
\hline Samples & Giardia & Cryptosporidium \\
\hline SABF Ph1 & + & + \\
SC Ph1 & + & + \\
CW Ph1 & + & + \\
\hline SABF Ph2 & + & + \\
SC Ph2 & + & + \\
CW Ph2 & + & + \\
\hline SABF Ph3 & + & + \\
\hline SC Ph3 & + & + \\
\hline CW Ph3 & + & + \\
\hline
\end{tabular}

Microorganisms of the genera Giardia and Cryptosporidium are commonly found in dog fecal samples; however, there are few studies on the role of dogs in zoonotic parasite transmission, although it is known that dog feces are a potential source of infection by these microorganisms (Julien et al. 2019).

\subsection{Evaluation of the PFA-WWTP as a whole}


Analysis of the PFA-WWTP treatment system as a whole (Table 5) shows that Ph3, in addition to presenting satisfactory organic matter concentrations at the WWTP outlet (P6) (Figure $3 \mathrm{f}$ and i), showed higher removal efficiency than that established by law for COD (70\%) and BOD (75\%) (Minas Gerais 2008) (Table 5). In the other phases, the removal efficiency reached the standards established by law only for BOD. Therefore, the addition of more aeration time, with intermittent supply into the biofilter, contributed to $\mathrm{N}$ removal and COD stabilization, which was high in the effluent studied, as in the study by Hasan et al. (2014).

Table 5

Mean removal efficiencies and standard deviation of COD, BOD, TS, SS, TP, TKN, ThermC and TN in the PFA-WWTP, in the different aeration phases

\begin{tabular}{|c|c|c|c|c|c|c|c|c|}
\hline \multirow[t]{2}{*}{ Phase } & \multicolumn{7}{|c|}{ P1A+P1B a P6 (\%) } & \multirow{2}{*}{$\begin{array}{l}\text { P3 a P6 (\%) } \\
\text { TN }\end{array}$} \\
\hline & COD & BOD & TS & SS & TP & TKN & Thermc & \\
\hline Ph1 & $30 \pm 26 B$ & $89 \pm 9 A B$ & $34 \pm 25 \mathrm{~A}$ & $48 \pm 38 \mathrm{~A}$ & $30 \pm 30 \mathrm{~A}$ & $50 \pm 30 \mathrm{~A}$ & $4 \pm 6 \log$ & $35 \pm 33 \mathrm{~A}$ \\
\hline $\mathrm{Ph} 2$ & $66 \pm 25 A$ & $90 \pm 8 \mathrm{~A}$ & $34 \pm 22 \mathrm{~A}$ & $70 \pm 29 A$ & $10 \pm 14 \mathrm{~A}$ & $23 \pm 31 A B$ & $5 \pm 1 \log$ & $34 \pm 30 \mathrm{~A}$ \\
\hline $\mathrm{Ph} 3$ & $71 \pm 20 A$ & $77 \pm 19 B$ & $43 \pm 27 \mathrm{~A}$ & $43 \pm 27 \mathrm{~A}$ & $14 \pm 21 \mathrm{~A}$ & $7 \pm 22 B$ & $1 \pm 0 \log$ & $14 \pm 17 \mathrm{~A}$ \\
\hline
\end{tabular}

The removal of SS was satisfactory in all phases, despite the accumulation and dragging of the material in the SC and $\mathrm{CW}$ in $\mathrm{Ph} 3$, due to the greater sludge generation in the SABF with the greater oxygen supply. Possibly for this reason, the removal efficiency of TKN was low in this phase, while P removal did not differ statistically (Tables 3 and 5).

However, the concentration of N (TKN and NT) at the WWTP outlet (P6) in Ph3 (Figures 2r and 3c) was close to the legal limit. This shows that the treatment system has the capacity to provide efficient $\mathrm{N}$ removal, and this aeration strategy can be adopted, as observed by Pelissari et al. $(2017 ; 2018)$. However, a shorter interval between SC cleanings should be adopted to take advantage of the potential of the operating condition.

The accumulation and dragging of sludge in Ph3 may also have been factors that reduced the efficiency of ThermC inactivation because the system showed good removal of microorganisms in Ph1, beginning after the SCs were cleaned, and in Ph2, in which cleaning was performed through monitoring (Table 3). Ph3 included the aggravating factor of higher sludge generation and lack of cleaning in the monitored period, as explained by Avelar et al. (2014).

\section{Conclusion}

The anaerobic treatment composed of the ST-ANF units was not sufficient for compliance with the legislation for the discharge of the treated wastewater from PFA into the local watercourse, especially regarding the variables COD and N. This justifies the use of subsequent post-treatment steps.

Post-treatment of the wastewater from PFA with an SABF, an SC, and CWs increased the treatment efficiencies, and the operation of the SABF with intermittent aeration every 2 hours provided the best results in terms of terms of nitrification/denitrification and organic matter removal (even being less biodegradable). Under this condition, in $\mathrm{Ph} 3$, the effluent COD was removed, and nitrification rate was greater.

In general, the SC acted in the retention of solids and phosphorus incorporated in the sludge and in denitrification. The SABF + SC combination was responsible for the removal of $\mathrm{N}$ in the PFA-WWTP, while the CWs exerted a polishing function, removing the remaining COD and $\mathrm{N}$ by SND, and acted in filtration, retaining solids, and dragging $\mathrm{P}$ and $\mathrm{N}$ from the SC.

The implementation of mechanisms for discharging the accumulated sludge in the SCs at intervals of up to 6 months is recommended to ensure greater nutrient and pathogenic microorganism removal efficiencies. The amount to be discarded should be better evaluated to prevent reduction of the denitrification capacity of the SC due to anoxic conditions in the presence of the sludge.

The quantification of Giardia cysts and Cryptosporidium oocysts at the inlet and outlet of the system is recommended to correlate the density of these microorganisms to the high presence of coliforms. Methods for improving the quality of the treatment system, such

Page $10 / 17$ 
as adding a disinfection phase and considering, in addition to the removal of organic compounds, the removal of pathogenic microorganisms, can also be considered.

\section{Declarations}

\section{Statement}

I have not submitted my manuscript to a preprint server before submitting it to Environmental Science and Pollution Research.

\section{Others statements:}

\section{a) Ethics approval and consent to participate}

Not applicable

\section{b) Consent for publication}

Not applicable

\section{c) Availability of data and materials}

The datasets used and/or analysed during the current study are available from the corresponding author on reasonable request. This paper originates from the $\mathrm{PhD}$ work of the first and corresponding author.

\section{d) Competing interests}

The authors declare that they have no competing interests.

\section{e) Funding}

This work was funded by Fundação de Amparo à Pesquisa de Minas Gerais (FAPEMIG) (grant number TEC APQ 02879/13) and Coordenação de Aperfeiçoamento de Pessoal de nível Superior (CAPES) through a PhD scholarship.

\section{f) Authors' contributions}

ARS: Conducted the experiment and generated the data. This paper originates from the PhD work of the first and corresponding author.

MPM: Statistical analysis of data and assistance in data discussion.

LABS: Guidance and assistance in carrying out methodologies and interpretation of microbiological analysis data.

RF: Work orientation.

\section{g) Acknowledgements}

The authors would like to thank the DESA/UFMG Water and Effluent Microbiology Laboratory, Francisco de Assis Park, FAPEMIG, CAPES and DAM/UFLA.

\section{References}

1. Adrados B, Sanchez O, Arias CA, Becares E, Garrido L, Mas J, Brix H, Morat J (2014) Microbial communities from different types of natural wastewater treatment systems: Vertical and horizontal flow constructed wetlands and biofilters. Water Research 55: 304312. https://doi.org/10.1016/j.watres.2014.02.011

2. Affandi IE, Suratman NH, Abdullah S, Ahmad WA, Zakaria ZA (2014) Degradation of oil and grease from high-strength industrial effluents using locally isolated aerobic biosurfactant-producing bacteria. International Biodeterioration \& Biodegradation 95: 3340. https://doi.org/10.1016/j.ibiod.2014.04.009 
3. APHA, AWWA, WEF (2005) Standard methods for the examination of water and wastewater, 21st edn. American Public Health Association, Washington, DC

4. Avelar FF, Matos AT, Matos MP, Borges AC (2014) Coliform bacteria removal from sewage in constructed wetlands planted with Mentha aquatica. Environmental Technology 35: 2095-2103. https://doi.org/10.1080/09593330.2014.893025

5. Brix H, Schierup HH (1989) The use of aquatic macrophytes in water-pollution control. Ambio 28: 100-107

6. Beltran CAE (2008) Aplicación de un sistema de control supervisor de pH y OD en la operación continua de un reactor nitrificante de disco rotatório. Universidad de La Frontera

7. Chernicharo CAL (2007) Reatores anaeróbios. Princípios do tratamento biológico de águas residuárias 5: 246, Belo Horizonte

8. Dong Z, Sun T (2007) A potential new process for improving nitrogen removal in constructed wetlands-Promoting coexistence of partial-nitrification and ANAMMOX. Ecological Engineering 31: 69-78. https://doi.org/10.1016/j.ecoleng.2007.04.009

9. Eerkes-Medrano D, Thompson RC, Aldridge DC (2015) Microplastics in freshwater systems: A review of the emerging threats, identification of knowledge gaps and prioritisation of research needs. Water Research 75: 63-82. https://doi.org/10.1016/j.watres.2015.02.012

10. Fan J, Zhang J, Ngo HH, Guo W, Yin X (2016) Improving low-temperature performance of surface flow constructed wetlands using Potamogeton crispus L. plant. Bioresource Technology 218: 1257-1260. https://doi.org/10.1016/j.biortech.2016.06.110

11. Fowler D, Coyle M, Skiba U, Sutton MA, Cape JN, Reis S, Sheppard LJ, Jenkins A, Grizzetti B, Galloway JN, Vitousek P, Leach A, Bouwman AF, Butterbach-Bahl K, Dentener F, Stevenson D, Amann M, Voss M (2013) The global nitrogen cycle in the twenty-first centuryPhil. Philosophical Transactions of the Royal Society B 368:1-13. https://doi.org/10.1098/rstb.2013.0164

12. Franco CS, Fia R, Mafra DCB, Vilela HS, Landim DV, Souza AR (2018) Operação do sistema de tratamento de dejetos do Parque Francisco de Assis, Lavras MG - Boletim Técnico. Lavras

13. Gao Y, Yu G, Luo C, Zhou P (2012) Groundwater Nitrogen Pollution and Assessment of Its Health Risks: A Case Study of a Typical Village in Rural-Urban Continuum, China. Plos One 7: 1-9. https://doi.org/10.1371/journal.pone.0033982

14. Ge S, Wang S, Yang X, Qiu S, Li B, Peng Y (2015) Detection of nitrifiers and evaluation of partial nitrification for wastewater treatment: A review. Chemosphere 140: 85-98. https://doi.org/10.1016/j.chemosphere.2015.02.004

15. Giongo A, Bortoli M, Prá MC, Veruck M, Kunz A (2018) Swine wastewater nitrogen removal at different C/N ratios using the modified ludzack-ettinger process. Engenharia Agrícola 38: 968-977. https://doi.org/10.1590/1809-4430-Eng.Agric.v38n6p968$977 / 2018$

16. Giustina SVD, Miranda LAS, Monteggia LO (2010) Remoção de matéria orgânica e sólidos suspensos por nova configuração de biofiltro aeróbio submerso no pós-tratamento de efluente de reator UASB. Engenharia Sanitária e Ambiental 15: 257-266. https://doi.org/10.1590/S1413-41522010000300009

17. Hasan HA, Abdullah SRS, Kamarudin SK, Kofli NT, Anuar N (2014) Kinetic evaluation of simultaneous COD, ammonia and manganese removal from drinking water using a biological aerated filter system. Separation and Purification Technology 130: 5664. https://doi.org/10.1016/j.seppur.2014.04.016

18. Henrique IN, Sousa JT, Ceballos BSO, Brasil DP (2010) Remoção biológica de fósforo em reatores em bateladas sequenciais com diferentes tempos de retenção de sólidos. Engenharia Sanitária e Ambiental 15:197-204. https://doi.org/10.1590/S141341522010000200012

19. He T, Li Z, Sun Q, Xu Y, Ye Q (2016) Heterotrophic nitrification and aerobic denitrification by Pseudomonas tolaasii Y-11 without nitrite accumulation during nitrogen conversion. Bioresource Technology 200: 493-499. https://doi.org/10.1016/j.biortech.2015.10.064

20. He Y, Wang X, Xu J, Yan H, Ge Q, Gu X, Jian L (2013) Application of integrated ozone biological aerated filters and membrane filtration in water reuse of textile effluents. Bioresource Technology 133: 150-157. https://doi.org/10.1016/j.biortech.2013.01.074

21. Huang M, Wang Z, Qi R (2017) Enhancement of the complete autotrophic nitrogen removal over nitrite process in a modified single-stage subsurface vertical flow constructed wetland: Effect of saturated zone depth. Bioresource Technology 233: 191-199. https://doi.org/10.1016/j.biortech.2017.02.100

22. llyas H, Masih I (2017) The performance of the intensified constructed wetlands for organic matter and nitrogen removal: A review. Journal of Environmental Management 198: 372-383. https://doi.org/10.1016/j.jenvman.2017.04.098

23. Kinh CT, Riya S, Hosomi MA (2017) Terada Identification of hotspots for NO and N2O production and consumption in counterand co-diffusion biofilms for simultaneous nitrification and denitrification. Bioresource Technology 245: 318-324.

Page 12/17 
https://doi.org/10.1016/j.biortech.2017.08.051

24. Jordão EP, Pessoa CA (2017) Tratamento de esgotos domésticos. ABES - Associação Brasileira de Engenharia Sanitária, Rio de Janeiro

25. Julien DA, Sargeant JM, Guy RA, Shapiro K, Imai RK, Bunce A, Sudlovenick E, Chen S, Li J, Harper SL (2019) Prevalence and genetic characterization of Giardia spp. and Cryptosporidium spp. in dogs in Iqaluit, Nunavut, Canada. Zoonoses and Public Health 66: 813-825. https://doi.org/10.1111/zph.12628

26. Korniłłowicz-Kowalska T, Bohacz J (2011) Biodegradation of keratin waste: Theory and practical aspects. Waste Management 31: 1689-1701. https://doi.org/10.1016/j.wasman.2011.03.024

27. Lamego Neto LG, Costa RHR (2011) Tratamento de esgoto sanitário em reator híbrido em bateladas sequenciais: eficiência e estabilidade na remoção de matéria orgânica e nutrientes (N, P). Engenharia Sanitária e Ambiental 16: 411-420. https://doi.org/10.1590/S1413-41522011000400013

28. Li XK, Chu ZR, Liu YJ, Zhu M, Yang L, Zhang J (2013) Molecular characterization of microbial populations in full-scale biofilters treating iron, manganese and ammonia containing groundwater in Harbin, China. Bioresource Technology 147: $234-239$. https://doi.org/10.1016/j.biortech.2013.08.008

29. Lizama K, Fletcher TD, Sun G (2011) Removal processes for arsenic in constructed wetlands. Chemosphere 84: 1032-1043. https://doi.org/10.1016/j.chemosphere.2011.04.022

30. Luesken FA, Van Alen TA, Van Der Biezen E, Frijters C, Toonen G, Kampman C, Hendrickx TLG, Zeeman G, Temmink H, Strous M, Op Den Camp HJM, Jetten MS (2011) Diversity and enrichment of nitrite-dependent anaerobic methane oxidizing bacteria from wastewater sludge. Applied Microbiology and Biotechnology 92: 845-854. https://doi.org/10.1007/s00253-011-3361-9

31. Matos AT, Matos MP (2017) Disposição de águas residuárias no solo e em sistemas alagados construídos. Editora UFV, Viçosa.

32. Matos MP, Von Sperling M, Matos AT (2018) Clogging in horizontal subsurface flow constructed wetlands: influencing factors, research methods and remediation techniques. Reviews in Environmental Science and Bio/Technology 17: 87-107. https://doi.org/10.1007/s11157-018-9458-1

33. Merrettig-Bruns U, Jelen E (2009) Anaerobic biodegradation of detergent surfactants. Materials 2: 181-206. https://doi.org/10.3390/ma2010181

34. Minas Gerais (2008) Deliberação Normativa Conjunta COPAM/CERH-MG nº 01, de 05 de maio.

35. Metcalf \& Eddy (2003) Wastewater Engineering: Treatment and Reuse. McGraw-Hill, New York.

36. Moura FN, Batista RO, Silva JBA, Feitosa AP, Costa MS (2011) Desempenho de sistema para tratamento e aproveitamento de esgoto doméstico em áreas rurais do semiárido brasileiro. Engenharia Ambiental: Pesquisa e Tecnologia 8: 264-276.

37. Nascimento CA, Staggemeier R, Bianchi E, Rodrigues MT, Fabres R, Soliman MC, Bortoluzzi M, Luz RB, Heinzelmann LS, Santos EL, Fleck JD, Spilki FR (2015) Monitoring of metals, organic compounds and coliforms in water catchment points from the Sinos River basin. Brazilian Journal of Biology 75: 50-56. https://doi.org/10.1590/1519-6984.1613

38. Nazari-Sharabian M, Ahmad S, Karakouzian M (2018) Climate Change and Eutrophication: A Short Review. Engineering, Technology and Applied Science Research 8: 3668-3672. https://doi.org/10.48084/etasr.2392

39. Nocko LM (2008) Remoção de carbono e nitrogênio em reator de leito móvel submetido à aeração intermitente. Dissertação, Universidade de São Paulo

40. Oliveira SMAC, Von Sperlig M (2005) Avaliação de 166 ETEs em operação no país, compreendendo diversas tecnologias. Parte 1 Análise de desempenho. Engenharia Sanitaria e Ambiental 10: 347-357. https://doi.org/10.1590/S1413-41522005000400012

41. Pelaz L, Gomez A, Letona A, Garralon G, Fdz-Polanco M (2018) Nitrogen removal in domestic wastewater. Effect of nitrate recycling and COD/N ratio. Chemosphere 212: 8-14. https://doi.org/10.1016/j.chemosphere.2018.08.052

42. Pelissari C, Avila C, Maria C, Trein CM, García J, Armas RD, Sezerino PH (2017) Nitrogen transforming bacteria within a full-scale partially saturated vertical subsurface flow constructed wetland treating urban wastewater. Science of The Total Environment 574: 390-399. https://doi.org/10.1016/j.scitotenv.2016.08.207

43. Pelissari C, Guivernau M, Vinas M, Garcia J, Velasco M, Souza SS, Sezerino PH, Ávila C (2018) Effects of partially saturated conditions on the metabolically active microbiome and on nitrogen removal in vertical subsurface flow constructed wetlands. Water Research 141: 185-195. https://doi.org/10.1016/j.watres.2018.05.002 
44. Priya VS, Philip L (2015) Treatment of volatile organic compounds in pharmaceutical wastewater using submerged aerated biological filter. Chemical Engineering Journal 266: 309-319. https://doi.org/10.1016/j.cej.2014.12.048

45. Ramos NFS, Borges AC, Gonçalves GC, Matos AT (2017) Tratamento de águas residuárias de suinocultura em sistemas alagados construídos, com Chrysopogon zizanioides e Polygonum punctatum cultivadas em leito de argila expandida. Engenharia Sanitária e Ambiental 22: 123-132. https://doi.org/10.1590/S1413-4152201687067

46. Saeed T, Sun G (2017) Pollutant removals employing unsaturated and partially saturated vertical flow wetlands: A comparative study. Chemical Engineering Journal 325: 332-341. https://doi.org/10.1016/j.cej.2017.05.072

47. Samsó R, García J (2013) Bacteria distribution and dynamics in constructed wetlands based on modelling results. Science of The Total Environment, v. 461-462:430-440. https://doi.org/10.1016/j.scitotenv.2013.04.073

48. Sarmento AP, Borges AC, Matos AT (2012) Evaluation of Vertical-Flow Constructed Wetlands for Swine Wastewater Treatment. Water, Air and Soil Pollution 223: 1065-1071. https://doi.org/10.1007/s11270-011-0924-4

49. Silva FJA, Souza RO (2011) Turbidez e cloro residual livre na monitoração de ETE tipo tanque séptico seguido de filtro anaeróbio. Acta Scientiarum Technology 33: 407-413. https://doi.org/10.4025/actascitechnol.v33i4.9603

50. Souza AR (2015) Avaliação da eficiência do sistema de tratamento de efluentes do canil Parque Francisco de Assis em LavrasMG. Dissertação, Universidade de Federal de Lavras, Lavras

51. Souza AR. Fia R, Vilela HS, Mafra DCB, Landim DV, Franco CS (2018) Efficiency of the treatment system of wastewater at a kennel. Acta Scientiarum Technology 40: e36694. https://doi.org/10.4025/actascitechnol.v40i1.36694

52. Tao C, Peng T, Feng C, Chen N, Hua Q, Hao C (2016) The feasibility of an up-flow partially aerated biological filter (U-PABF) for nitrogen and COD removal from domestic wastewater. Bioresource Technology, 218: 307-317. https://doi.org/10.1016/j.biortech.2016.06.098

53. Taylor CR, Hook PB, Stein OR, Zabinksi CA (2011) Seasonal effects of 19 plant species on COD removal in subsurface treatment wetland microcosms. Ecological Engineering 37: 703-710. https://doi.org/10.1016/j.ecoleng.2010.05.007

54. Toscano A, Marzo A, Milani M, Cirelli G, Barbagallo S (2015) Comparison of removal efficiencies in Mediterranean pilot constructed wetlands vegetated with different plant species. Ecological Engineering 75: 155-160. https://doi.org/10.1016/j.ecoleng.2014.12.005

55. Vilela CLS, Bassin JP, Peixoto RS (2018) Water contamination by endocrine disruptors: Impacts, microbiological aspects and trends for environmental protection. Environmental Pollution 235: 546-559. https://doi.org/10.1016/j.envpol.2017.12.098

56. Vivan M, Kunz A, Stolberg J, Perdomo C, Techio VH (2010) Eficiência da interação biodigestor e lagoas de estabilização na remoção de poluentes em dejetos de suínos. Revista Brasileira de Engenharia Agrícola e Ambiental 14: 320-325. https://doi.org/10.1590/S1415-43662010000300013

57. Von Sperling M (2017) Introdução à qualidade das águas e ao tratamento de esgotos: Princípios do tratamento biológico de águas residuárias. UFMG, Belo Horizonte

58. Von Sperling M. Lodos ativados: Princípios do tratamento biológico de águas residuárias. UFMG, Belo Horizonte.

59. Yang H, Zhang Y, Ye Y (2012) Study on the Dissolved Oxygen (DO) on the Short-cut Nitrification in Sequencing Batch Reactor (SBR). Advanced Materials Research 374-377: 1009-1012. https://doi.org/10.4028/www.scientific.net/AMR.374-377.1009

60. Yao Q, Peng DC (2017) Nitrite oxidizing bacteria (NOB) dominating in nitrifying community in full-scale biological nutrient removal wastewater treatment plants. AMB Express 7: 1-11. doi:http://dx.doi.org/10.1186/s13568-017-0328-y

61. Zeng RJ, Lemaire R, Yuan Z, Keller J (2003) Simultaneous Nitrification, Denitrification, and Phosphorus Removal in a Lab-Scale Sequencing Batch Reactor. Biotechnology Bioengineering 84: 170-178. https://doi.org/10.1002/bit.10744

62. Zhang Z, Pan S, Huang F, Li X, Shang J, Lai J, Laio Y (2017) Nitrogen and Phosphorus Removal by Activated Sludge Process: A Review. Mini-Reviews in Organic Chemistry 14: 99-106. https://doi.org/10.2174/1570193X14666161130151411

63. Zheng Z, Zhang D, Li W, Qin W, Huang X (2018) Substrates removal and growth kinetic characteristics of a heterotrophic nitrifyingaerobic denitrifying bacterium, Acinetobacter harbinensis HITLi7T at $2{ }^{\circ} \mathrm{C}$. Bioresource Technology 259: 286-293. https://doi.org/10.1016/j.biortech.2018.03.065

64. Zoppas FM, Bernardes AM, Meneguzzi A (2016) Parâmetros operacionais na remoção biológica de nitrogênio de águas por nitrificação e desnitrificação simultânea. Engenharia Sanitária e Ambiental 21: 29-42. https://doi.org/10.1590/S141341520201600100134682 


\section{Figures}

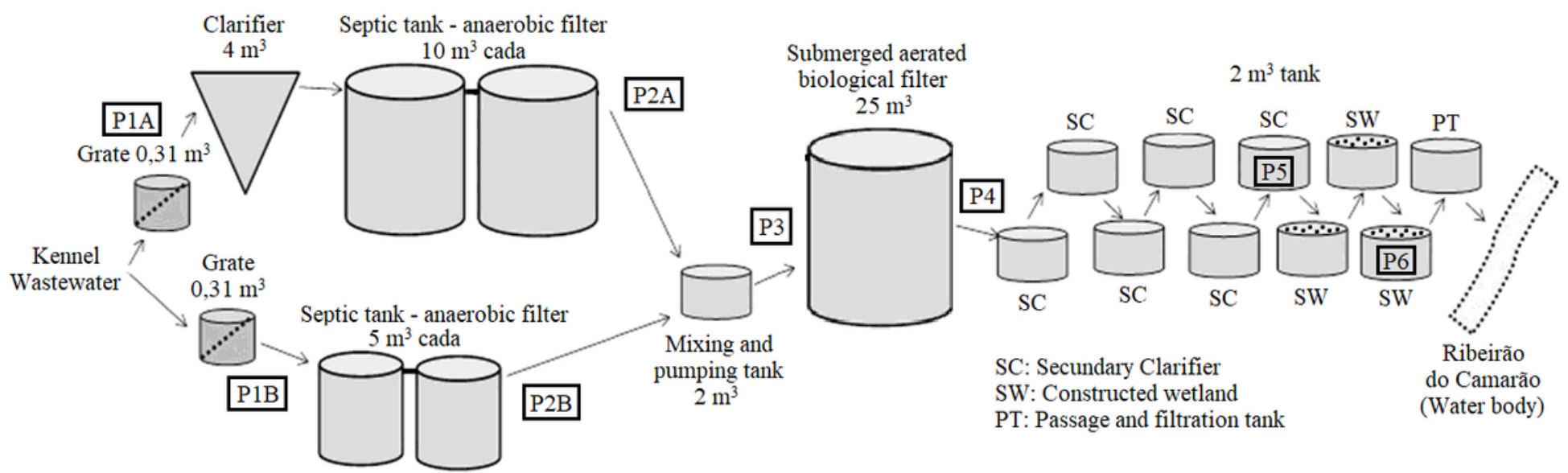

\section{Figure 1}

Schematic diagram of the wastewater treatment system generated in the washing of dog stalls in Parque Francisco de Assis de Lavras-MG 

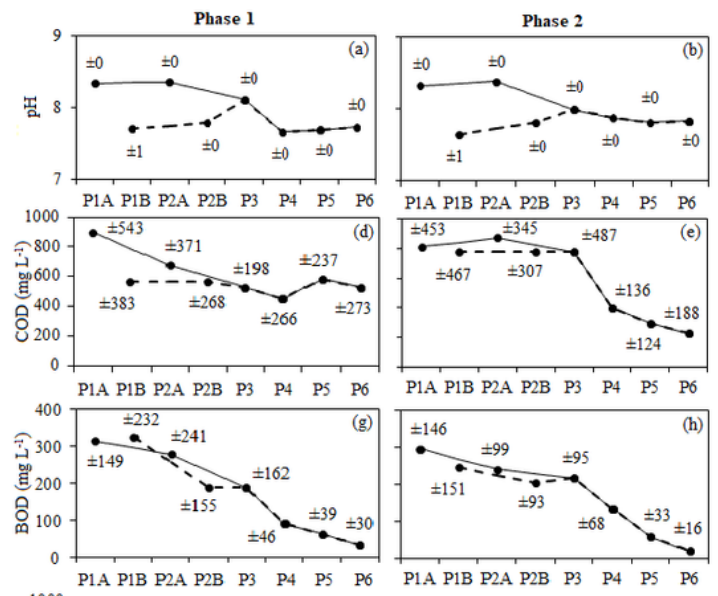

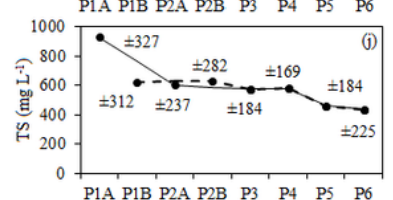
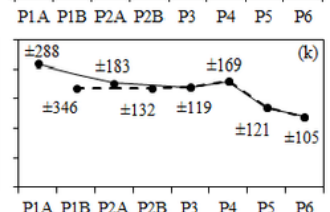

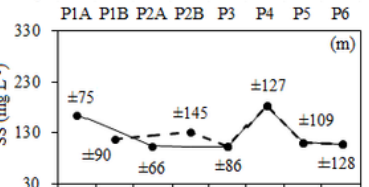

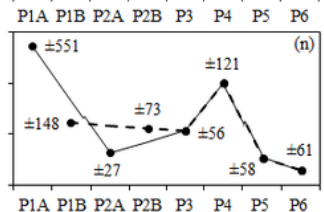

\begin{tabular}{lllll} 
P1A P1B P2A P2B & P3 & P4 & P5 & P6 \\
\hline 30
\end{tabular}

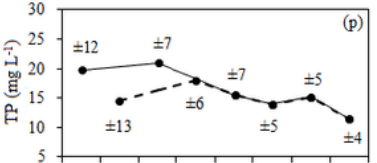

$\begin{array}{llllll}\text { P1A P1B P2A P2B } & \text { P3 } & \text { P4 } & \text { P5 } & \text { P6 }\end{array}$

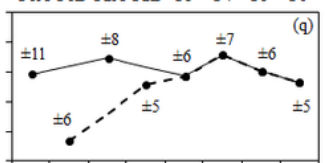

$\begin{array}{llllll}\text { P1A P1B P2A P2B } & \text { P3 } & \text { P4 } & \text { P5 } & \text { P6 }\end{array}$

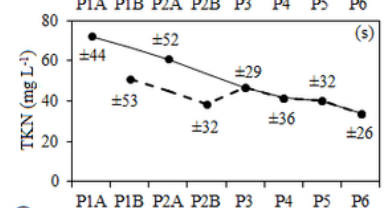

$\begin{array}{llllllllllllll}\text { P1A P1B P2A P2B } & \text { P3 } & \text { P4 } & \text { P5 } & \text { P6 } & \text { P1A P1B P2A P2B } & \text { P3 } & \text { P4 } & \text { P5 } & \text { P6 }\end{array}$
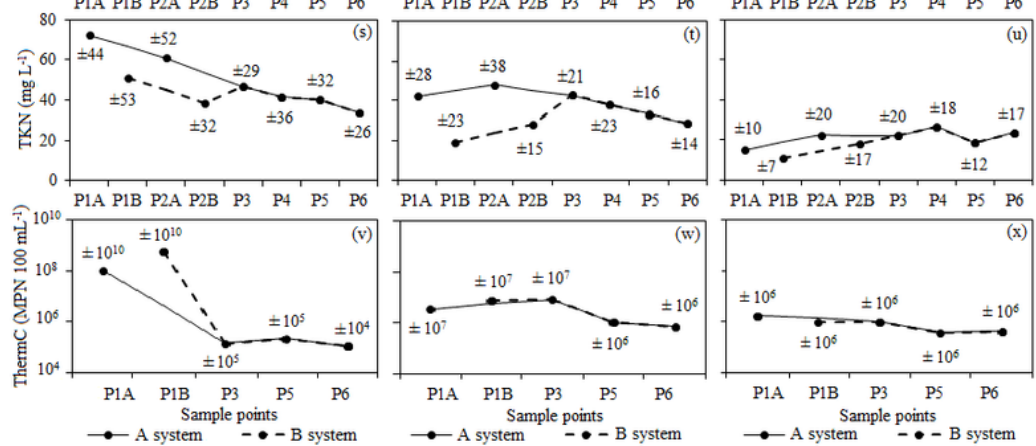

$\multimap$ A system
Phase 3

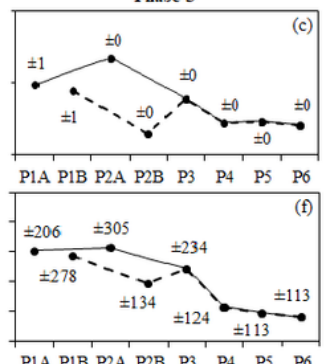

$\begin{array}{llllll}\text { P1A P1B P2A P2B } & \text { P3 } & \text { P4 } & \text { P5 } & \text { P6 }\end{array}$

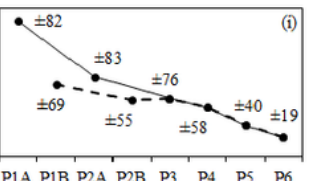

$=253 \quad \neq 1106 \quad$ (I)

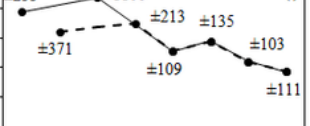

$\begin{array}{lllll}\text { P1A P1B P2A P2B } & \text { P3 } & \text { P4 } & \text { P5 } & \text { P6 }\end{array}$
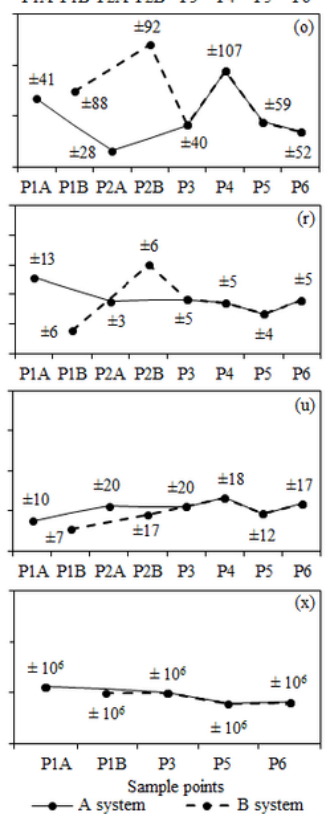

Figure 2

Mean values and standard deviation of $\mathrm{pH}, \mathrm{COD}, \mathrm{BOD}, \mathrm{TS}, \mathrm{SS}$, TP and TKN, geometric means with standard deviation of ThermC, of the ETE-PFA units, in the different aeration phases

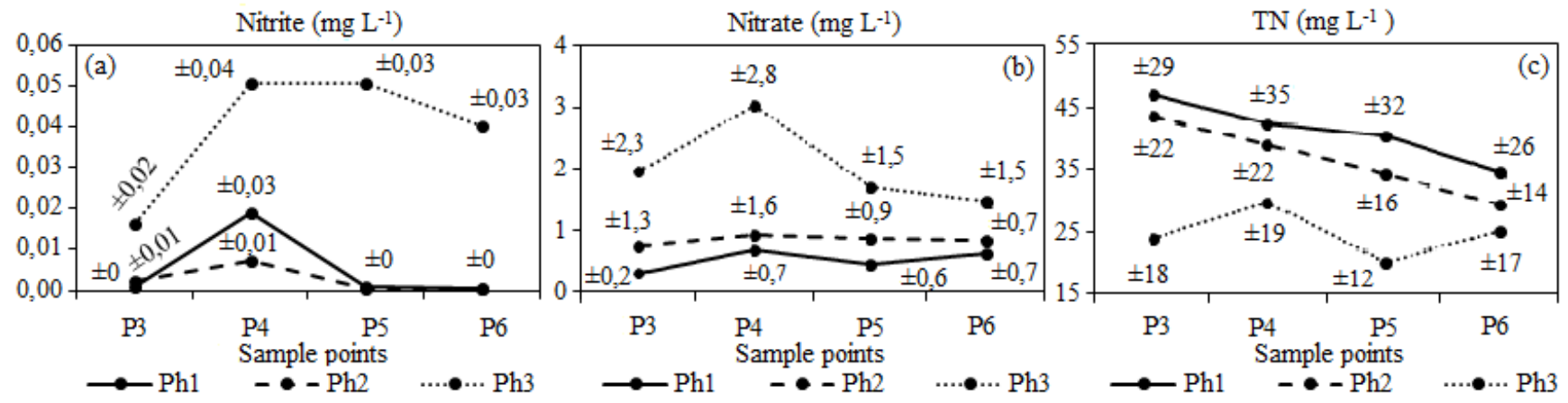

Figure 3

Mean values and standard deviation of nitrite, nitrate and TN (total nitrogen) in the aerobic post-treatment (SABF, SC and CW), in the different aeration phases, of the PFA-WWTP 


\section{Supplementary Files}

This is a list of supplementary files associated with this preprint. Click to download.

- GraphicalAbstract600dpi.tif 